\title{
Breeding biology of Purple Sandpipers Calidris maritima on the Hardangervidda, southern Norway
}

\author{
Häckningsbiologin hos skärsnäppa Calidris maritima på Hardangervidda, \\ södra Norge
}

RAB RAE, MIKE NICOLL, RON SUMMERS, STUART RAE \& KEITH BROCKIE

\begin{abstract}
Breeding Purple Sandpipers Calidris maritima were studied within an area of approximately $32 \mathrm{~km}^{2}$ on the Hardangervidda, southern Norway during 1978 to 1986. The minimum average density was 1.0 pairs per $\mathrm{km}^{2}$ in 1984. Clutch sizes were 3-4 (mean = 3.74), and egg sizes were small, reflecting the small size of the females compared to other populations. Hatching was in late June and clutch survival was $75 \%$. The eggs in one nest were believed to have been trampled by a Reindeer. Chick growth was described for two broods. Broods were mostly attended by males. Only $8 \%$ ( 2 of 24 broods) were attended by females. Adult masses declined during the breeding season, supporting the theory that brood desertion by Arctic-breeding sandpipers could be related to loss of condition in the breeding adults. However, females, who usually desert the brood, did not decline in mass any faster than males. Birds from one pair were

faithful to mate and site; the birds wintered apart (the female was seen in winter) and the pair re-united on the breeding territory.

Rab Rae, 11 Millend, Newburgh, Aberdeenshire, AB41 6DX, Scotland.Email: rab.rae@wellheads.co.uk Mike Nicoll, 1 Banknowe Grove, Tayport, Fife, DD6 9LH, Scotland.

Ron Summers, Lismore, Mill Crescent, North Kessock, Inverness, IV1 3XY, Scotland.

Email: ron.summers@rspb.org.uk

Stuart Rae, Research School of Biology, Building 116, Daley Road, Australian National University, Canberra, ACT 0200, Australia.

Keith Brockie, Fearnan Gallery, Fearnan, Aberfeldy, Perthshire, PH15 2PG, Scotland.
\end{abstract}

Received 8 February 2011, Accepted 3 October 2011, Editor: Å. Lindström

\section{Introduction}

The Purple Sandpiper Calidris maritima is an Arctic-breeding sandpiper that nests in Canada, Greenland, Iceland, Fennoscandia, Svalbard and Russia (Cramp \& Simmons 1983). Its breeding range extends south as far as Hudson Bay, Canada, and the mountains of southern Norway and Scotland. Most information on the bird's breeding biology is from the high Arctic, particularly Svalbard where there is a high nesting density (Løvenskiold 1964, de Korte 1972, Bengtson 1975, Pierce 1997, Summers $\&$ Nicoll 2004). Less is known about the southern populations (e.g. Scotland, Smith \& Summers 2005). Swanberg (1945) made a series of observations in the Swedish mountains and the only study of breeding Purple Sandpipers in the Norwegian mountains was by the 1978 Cambridge University Expedition (Innes 1979, Cane 1979). One of our group $(\mathrm{KB})$, took part in this trip and we then con- tinued to visit the same area and extended the observations during 1980 to 1986 . Results from these studies have described adult biometrics (Nicoll et al. 1991), incubation scheduling (Cresswell \& Summers 1988) and their migration using ringing recoveries (Rae et al. 1986). This paper complements these by describing the breeding biology of Purple Sandpipers on the Hardangervidda; in particular the nesting density, time of breeding, clutch and egg size, hatching success, chick growth, and fidelity to mate and site.

\section{Study area and methods}

The study area was approximately $32 \mathrm{~km}^{2}$ on the Hardangervidda $\left(60^{\circ} \mathrm{N}, 7^{\circ} \mathrm{E}\right)$, a mountain plateau (c. $1200 \mathrm{~m}$ altitude) in southern Norway (Figure 1). The habitat was mainly dry heath (Vaccinium and Empetrum species) on raised ground, and mires (comprising Carex and Salix species and mosses) 


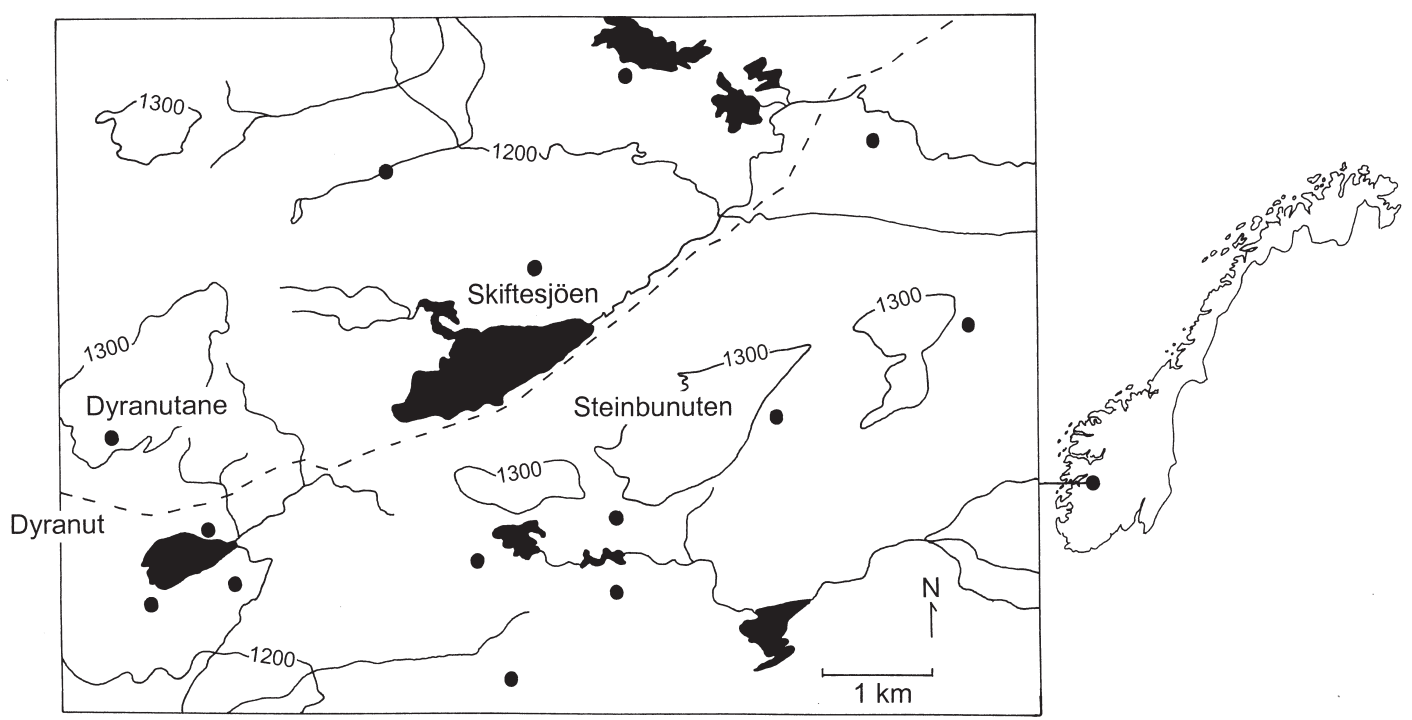

Figure 1. The study area on the Hardangervidda, south Norway. $\bullet$ locations of nests and broods in 1984 . The dashed line is a road, the black areas are lakes and the numbers are contour heights in metres.

Undersökningsområdet på Hardangervidda i södra Norge. • platser för bon och kullar 1984. Den streckade linjen är en väg, de svara områdena sjöar och talen höjder i meter.
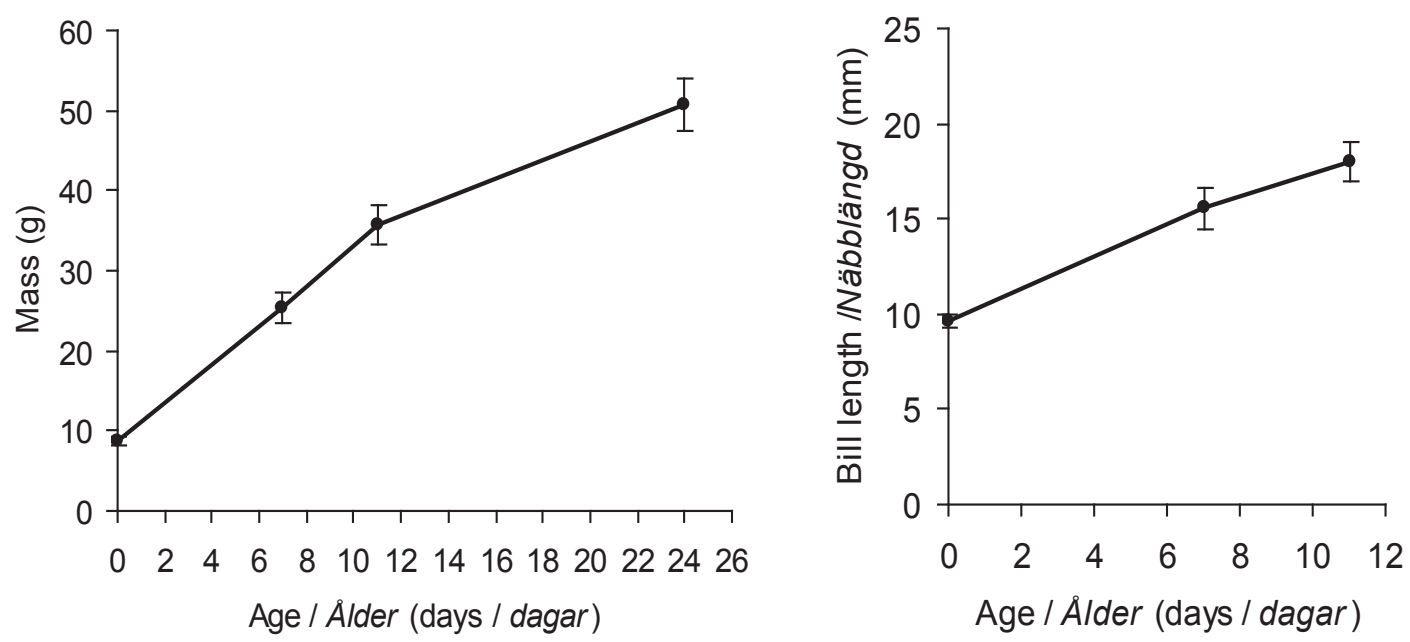

Figure 2. Growth of five Purple Sandpiper chicks from two broods on the Hardangervidda. Vertical lines show standard deviations from the means.

Tillväxten för fem skärsnäppeungar från två kullar på Hardangervidda. Vertikala linjer visar stadardavvikelser från medelvärdena. 
Table 1. Timing of visits to the Hardangervidda and hatch dates of the Purple Sandpipers. There were significant differences between years in hatch dates $\left(\mathrm{F}_{4,33}=5.6, \mathrm{P}=0.001\right.$. $)$.

Besökstider på Hardangervidda och kläckdatum för skärsnäppor. Det var signifikant skillnad mellan år för kläckdatum $\left(F_{4,33}=5,6, P=0,001\right)$.

\begin{tabular}{lcccc}
\hline Year & Dates & $\begin{array}{c}\text { No. of observers } \\
\text { (man-days) } \\
\text { Antal observatörer } \\
\text { (man-dagar) }\end{array}$ & $\begin{array}{c}\text { Mean hatch date } \\
\text { (range) } \\
\text { Medeldatum kläckning } \\
\text { (spridning) }\end{array}$ & $\begin{array}{c}\text { No. of nests and } \\
\text { broods } \\
\text { Antal bon och } \\
\text { kullar }\end{array}$ \\
\hline 1978 & 7 June-26 July & $2(100)$ & 5 July (26 June-16 July) & 9 \\
1980 & 29 June-10 July & 7 & 23 June (14-28 June) & 4 \\
1981 & 13-24 June & - & 24 June (19 June-9 July) & 6 \\
1982 & 25 May-2 July & $5(81)$ & - & - \\
1983 & 30 June-9 July & $4(39)$ & - & - \\
1984 & 14 June-8 July & $6(54)$ & 29 June (25 June-5 July) & 16 \\
1985 & 11 June-9 July & $7(108)$ & 29 June (27 June-1 July) & 3 \\
1986 & 27-30 June & $2(8)$ & - & - \\
\hline
\end{tabular}

in dips and hollows (Cresswell \& Summers 1988). The vegetation types and climate have been described by Lien et al. (1974), Byrkjedal (1989) and Østbye et al. (2002).

The study area was visited in late June and/or early July each year during 1978 to 1986, apart from 1979 (Table 1). Breeding density was calculated from the mean nearest-neighbour distance between nests and/or broods. Ground clear of lying snow was searched for nests and areas around nest sites of previous years were searched thoroughly. As incubating Purple Sandpipers do not flush readily from their nests, a branch (c. $1.5 \mathrm{~m}$ long) was swept from side to side in front of the observer to disturb birds. However, because few nests were found, breeding density was assessed more on broods located. Adult birds attending chicks alarmed at the approach of observers (from 50-200 $\mathrm{m})$. Brood density gave only a minimum estimate of nesting density because we may not have found all of them. However, we did account for lost nests in this estimate.

The length and breadth of eggs were measured with dial callipers, and egg mass recorded with a Pesola spring balance. Mean sizes were determined for all eggs within each clutch before calculating the averages for all clutches. Time of hatching was based on regular visits to nests and also from backcalculating hatching dates of chicks whose age was estimated from growth (see Figure 2). Bill lengths of chicks were measured with dial callipers to 0.1 $\mathrm{mm}$, foot length with a stopped ruler to $0.5 \mathrm{~mm}$ (Anderson 1975), and mass with a Pesola spring balance to $0.1 \mathrm{~g}$.
Clutch success was calculated following the Mayfield method (Mayfield 1975, Johnson 1979). The number of clutch losses was divided by the total nest days of observation to give the daily rate of loss, which was subtracted from 1 to give the daily success rate. This was then raised to the power of 25 (the laying plus incubation period) to estimate the probability of a clutch hatching.

Adults were captured with mist nets at nests or when with broods. Measurements taken were: maximum wing length to $1 \mathrm{~mm}$, foot length to 0.5 $\mathrm{mm}$ with a stopped ruler, bill length to $0.1 \mathrm{~mm}$ with dial callipers, and mass to $1 \mathrm{~g}$ with a Pesola balance. Purple Sandpipers are strongly dimorphic with respect to bill size; females have longer bills than males (Cramp \& Simmons 1983). Therefore, one can sex most individuals on bill length (Hallgrimsson et al. 2008). In an earlier analysis of Purple Sandpipers from the Hardangervidda, Nicoll et al. (1991) classed those with bill lengths less than $27.5 \mathrm{~mm}$ as male and those with bills over $27.4 \mathrm{~mm}$ as female. All birds were individually marked with metal rings and different permutations of coloured rings.

Nest attendance was recorded at one nest with an automatic camera, which took photographs every half hour through day-light hours, approximately 17 hours per day (03:00-24:00 hours). The percentage of photographs with an incubating bird was taken as a measure of nest attendance. The area within $1 \mathrm{~m}$ of five nests was photographed and the surrounding vegetation was subsequently described by the proportionate cover of each plant species, lichens or bare ground. 
Table 2. Biometrics of breeding Purple Sandpipers on the Hardangervidda. Biometri för häckande skärsnäppor på Hardangervidda.

\begin{tabular}{|c|c|c|c|c|c|c|}
\hline & \multicolumn{3}{|c|}{ Males Hanar } & \multicolumn{3}{|c|}{ Females Honor } \\
\hline & Mean (SD) & Range & $\begin{array}{l}\text { Sample } \\
\text { size }(N)\end{array}$ & Mean (SD) & Range & $\begin{array}{l}\text { Sample } \\
\text { size }(N)\end{array}$ \\
\hline Bill length (mm) & $24.7(0.98)$ & $22.5-27.2$ & 49 & $29.2(0.97)$ & $27.7-30.5$ & 18 \\
\hline Wing length (mm) & $125.7(2.5)$ & $118-131$ & 49 & $129.7(3.3)$ & $125-135$ & 18 \\
\hline Foot length (mm) & $47.6(0.6)$ & $46.5-48.5$ & 16 & $49.7(1.3)$ & $48-51.5$ & 5 \\
\hline Mass (g) & $55.2(4.9)$ & $49-67$ & 36 & $64.2(6.9)$ & $51-78$ & 14 \\
\hline
\end{tabular}

\section{Results}

Twenty-three nests were found, including the seven nests found in 1978 (Cane 1979). The only year when the hatching period was adequately covered to estimate the minimum nesting density was 1984 (Table 1). Three nests and 11 broods were found within approximately $32 \mathrm{~km}^{2}$. Chicks from the nests were ringed at hatching in the nests, thereby preventing double-counting of broods. Combining nests and broods, the mean nearest neighbour distance was $1.24 \mathrm{~km}(\mathrm{SD}=0.58$, range $=0.5-2.3$ $\mathrm{km})$, equivalent to a density of 0.8 pairs per $\mathrm{km}^{2}$ (Figure 1). Given that there was a 25\% nest loss (see below), and broods accounted for $79 \%$ of the density estimation, we adjusted the initial estimate of 0.8 pairs per $\mathrm{km}^{2}$ to 1.0 pairs per $\mathrm{km}^{2}$, thereby accounting for nest losses.

Nest sites were varied in their location, and often placed adjacent to a small rock or on top of a moss (Racomitrium) hummock. The nests were always in dry sites although wet ground was usually nearby; the mean distance from nest to nearest mire was $110 \mathrm{~m}(\mathrm{n}=6, \mathrm{SE}=40)$. Plant cover was short, allowing the incubating bird an uninterrupted view all around. The mean percentage cover of plants and other features within a metre of five nests was: 22\% Carex, 17\% rock, 16\% Empetrum, $12 \%$ Vaccinium, 12\% Salix, $8 \%$ lichens, $8 \%$ grass and $5 \%$ bare earth. The mean width of the nest cups was $86 \mathrm{~mm}(\mathrm{n}=9, \mathrm{SE}=1.9)$ and depth was 33 $\mathrm{mm}(\mathrm{n}=9, \mathrm{SE}=1.1)$. Nests were usually lined with lichen Cladonia spp., willow Salix herbacea leaves, and occasional leaves of Cloudberry Rubus chamaemorus and Dwarf Birch Betula nana. Most nests $(55 \%)$ were set on slopes with a northeast aspect. The prevailing wind is from the southwest, so northeast slopes are more sheltered. Other aspects were north (1 nest), east (2) and southeast (1). There was no instance of a pair re-using a nest scrape in a subsequent year for their clutch.

The average clutch size was $3.74(\mathrm{SD}=0.44$, range $=3-4)$. The mean length of the eggs was 36.2 $\mathrm{mm}(\mathrm{n}=8$ clutches, $\mathrm{SD}=0.7$, range $=35.3-37.3$ $\mathrm{mm})$ and the mean breadth was $25.8 \mathrm{~mm}(\mathrm{SD}=0.3$, range $=25.5-26.3 \mathrm{~mm})$. The mean mass of three eggs from one clutch was $11.9 \mathrm{~g}$ (range $=11.1$ $12.6 \mathrm{~g}, \mathrm{n}=3$ ) when freshly laid. Thus, a clutch of four eggs would have a mass of $47.6 \mathrm{~g}$. As breeding females have a mean mass of $64.2 \mathrm{~g}$ (Table 2), a typical clutch would represent $74 \%$ of a female's mass. Eggs lose mass during incubation and in one clutch the mean mass dropped from $11.7 \mathrm{~g}$ when the last egg was laid to $10.5 \mathrm{~g}$ at the end of incubation (Figure 3).

Hatching dates were known or calculated for 38 clutches and broods. Most chicks hatched in late June although the mean dates varied from 23 June to 5 July among years (Table 1). Twelve clutches were monitored for a total of 89 days, during which there was one nest failure. The daily survival rate was $0.9887(\mathrm{SE}=0.0112)$, which gave a clutch success of $75 \%$. The failure was believed to have

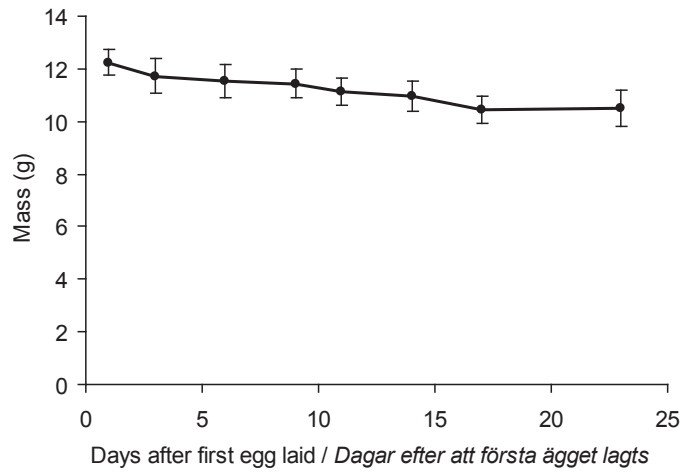

Figure 3. Changes in the mass (g) of three Purple Sandpiper eggs in one nest on the Hardangervidda. Vertical lines show standard deviations from the means.

Förändringen i massa ( $g$ ) för tre ägg av skärsnäppa i ett bo på Hardangervidda. Vertikala linjer visar standardavvikelsen från medelvärdena. 
been caused by a Reindeer Rangifer tarandus trampling the eggs because there were fresh Reindeer droppings and hoof prints close to the broken eggs in the nest.

The masses of chicks in seven broods were recorded at hatching and the mean mass was $8.2 \mathrm{~g}$ $(\mathrm{SD}=0.3 \mathrm{~g})$. For one brood measured at hatching the mean bill length was $9.9 \mathrm{~mm}$, and foot length was $44.8 \mathrm{~mm}$. After hatching, the chicks were led from the dry ridges and slopes where the nests were to nearby mires. The growth of chicks is shown in Figure 2.

Sixty-seven breeding birds were trapped and the bill length distribution was bimodal, with modes at $25 \mathrm{~mm}$ (males) and $30 \mathrm{~mm}$ (females) (Figure 4). Only two birds were in the overlap zone where sex was questionable. One had a bill length of 27.2 $\mathrm{mm}$ and the other $27.7 \mathrm{~mm}$. The bird with the bill at $27.2 \mathrm{~mm}$ was mated to one with a bill of 29.1 $\mathrm{mm}$, so were assumed to be male and female respectively. By contrast, the bird with the bill length of $27.7 \mathrm{~mm}$ was mated to one with a bill of 24.9 $\mathrm{mm}$, so they were assumed to be female and male respectively. Using $27.5 \mathrm{~mm}$ as the point of separation for the sexes, their biometrics were described (Table 2).

A total of 220 photographs were taken of an incubating pair during 21 to 27 June 1985. Birds were present incubating on 214 of these, giving a nest attendance of $97.3 \%$. Observations from a hide found that incubating birds walked off the nest once or twice during an incubation shift to feed in the immediate area of the nest for several minutes at a time. The masses of both sexes dropped during the breeding season and there was no evidence that females declined more than males (Figure 5). However, when the sexes were analysed separately, only the mass of the males declined significantly $(P<0.001)$, whilst the females $\operatorname{did} \operatorname{not}(P=0.18)$.

Most females, or occasionally the male, deserted the brood at hatching. Thereafter, a single adult, usually the male (22 out of 24 broods) attended the brood. The adults with broods classed as female had bill lengths of $30 \mathrm{~mm}$ and $28.9 \mathrm{~mm}$, so were well within the female mode (Figure 4). One of the females was found with small chicks (they still had the egg tooth), so it is possible that she departed later, leaving the male to attend the brood. Broods were taken up to $200 \mathrm{~m}$ from the nest, often to mires dominated by Bottle Sedge Carex rostrata with no standing water. Other brood habitats were moss-dominated tundra where the chicks often hid in spaces under rocks if alerted to danger by the attendant adult. The attendant adult usually stood on

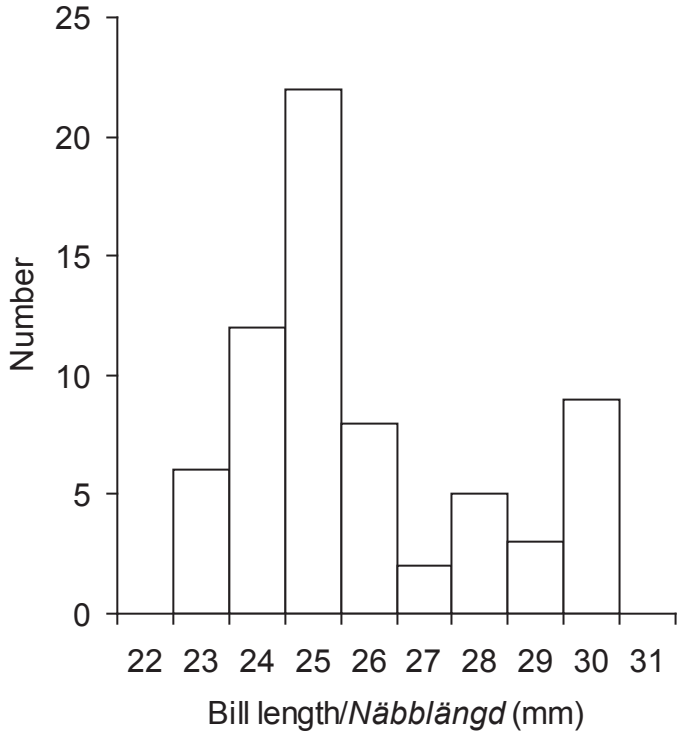

Figure 4. Frequency distribution of bill lengths of 67 breeding Purple Sandpipers from the Hardangervidda.

Fördelning av näbblängderna för 67 häckande skärsnäppor från Hardangervidda.

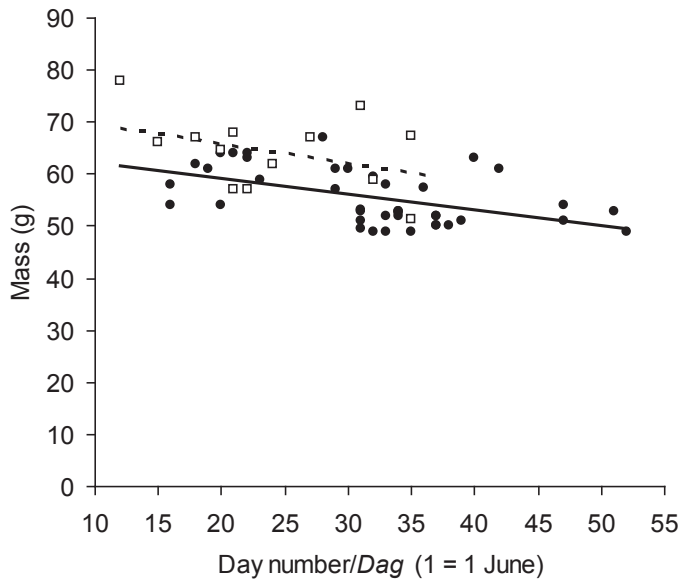

Figure 5. The changes in mass of male $(\bullet)$ and female $(\square)$ Purple Sandpipers during the breeding season. The regression equation was: Mass $=65.5(\mathrm{se}=2.8)-0.31(0.08)$ Day number $+6.42(1.8)$ Sex $($ female $=1$ and male $=0)$. The $\mathrm{P}$ values for day number and sex were $<0.001$. There was no significant interaction between day number and sex, $\mathrm{P}=0.71$ (i.e. no difference in the slopes).

Förändringen i massa hos hanar (•) och honor (ㅁ) av skärsnäppa under häckningstid. Regressionen var: Massa $=65,5$ $(s e=2.8)-0,31(0,08)$ dagsnummer $+6,42(1,8)$ kön (hona $=1$ och hane $=0)$. P-värdena för dagsnummer och kön var $<0,001$. Det fanns ingen signifikant interaktion mellan dagsnummer och kön, $P=0,71$ (dvs. ingen skillnad i lutning). 
Table 3. Observations of a pair of Purple Sandpipers on the same territory over five years. All observations were within an area of approximately 6 ha. The female was seen on the Isle of May, Fife, Scotland in autumns 1982, 1983 and 1984.

Observationer av ett par av skärsnäppa $i$ samma revir under fem år. Alla observationer inom ungefär 6 ha. Honan sågs på Isle of May, Fife, Scotland höstarna 1982, 1983 och 1984.

\begin{tabular}{cll}
\hline Year & Male Hane & Female Hona \\
\hline 1980 & $\begin{array}{l}\text { Caught on nest } \\
\text { Fangad på bo }\end{array}$ & - \\
1981 & $\begin{array}{l}\text { Seen at nest } \\
\text { Sedd vid bo }\end{array}$ & $\begin{array}{l}\text { Caught on nest } \\
\text { Fångad på bo }\end{array}$ \\
1982 & $\begin{array}{l}\text { Seen with mate } \\
\text { Sedd med maka }\end{array}$ & $\begin{array}{l}\text { Seen with mate } \\
\text { Sedd med make }\end{array}$ \\
Caught on nest & Caught on nest \\
1984 & $\begin{array}{l}\text { Fångad på bo } \\
\text { Caught with chicks } \\
\text { Fångad med ungar }\end{array}$ & Fångad på bo \\
& & \\
\hline
\end{tabular}

a prominent rock or hummock, looking out for any impending danger.

It was not possible to accurately quantify return rates of breeding adults each year during our short visits. However, some birds were recorded in subsequent years and were faithful to breeding sites and mates. The birds in one pair nested within the same area in three years, and the male was present in five (Table 3). All the nests of this pair were within $100 \mathrm{~m}$ of the original nest site, and two were within $20 \mathrm{~m}$ of the previous years' nest sites.

\section{Discussion}

In many respects, the breeding biology of Purple Sandpipers in south Norway is similar to that described elsewhere, in Svalbard (Bengtson 1975, Pierce 1997), Franz Josef Land (Tomkovich 1985) and Iceland (Summers \& Nicoll 2004). The main difference from those of more northern populations is that the egg sizes are smaller, reflecting the small size of birds on the Hardangervidda (Table 2, Summers \& Nicoll 2004).

The average nesting density of 1.0 pairs per $\mathrm{km}^{2}$ was typically low (Summers \& Nicoll 2004). This estimate was based largely on locating broods, but was adjusted to account for clutch loss. Elsewhere on the Hardangervidda, the mean density was estimated at 0.83 pairs within a $1 \mathrm{~km}^{2}$ plot during 1967-1972 at Finse (Lien et al. 1974). This and our value are low compared to the density of 2-3 pairs per $\mathrm{km}^{2}$ given for an unspecified but small part of the same study area on the Hardangervidda by Cane (1979), and 1.85 pairs $\mathrm{km}^{2}$ (range $0-5.6$ pairs per $\left.\mathrm{km}^{2}\right)$ in an alpine area at Nedal, central Norway (Moksnes 1973). However, because these higher values refer to only small areas on the Hardangervidda and at Nedal (a $0.18 \mathrm{~km}^{2}$ plot), they are probably not representative of these general areas.

Nest (clutch) success was similarly high to that found elsewhere in the breeding range of Purple Sandpipers (Summers \& Nicoll 2004). The one nest believed to have been trampled by Reindeer is an example of a chance phenomenon. A large herd of Reindeer roams the Hardangervidda and each year some nests of ground-nesting birds would likely be trampled. The generally high hatching success may be linked to the long incubation spells (only two change-overs per day; Creswell \& Summers 1988) and close sitting by incubating birds, thereby minimising the chance of predators detecting the birds and their nest.

Nest attendance was high $(97.3 \%)$, similar to other monogamous Calidris sandpipers, e.g. Dunlin Calidris alpina (97.5\%) and Baird's Sandpiper C. bairdii $(96.5 \%)$. This contrasts with that of polygamous species where the female incubates alone, e.g. White-rumped Sandpiper C. fuscicollis $(82.5 \%)$ and Pectoral Sandpiper C. melanotos (85\%) (Norton 1972).

Brood desertion by female Purple Sandpipers has been observed in most studies, as have instances of male desertion (Pierce 1997, Summers $\&$ Nicoll 2004). Several possible reasons for brood desertion have been put forward. One prominent theory is that loss in condition during the breeding season jeopardises future breeding attempts if birds remain with brood, particularly for the female who invests more (through egg production) in nesting (Ashkenazie \& Safriel 1979). Although there was a decline in the mass of both sexes (Figure 5), the females did not decline in mass at a faster rate than males. Also, when analysed alone, there was no statistically significant decline for females, though the sample size was smaller and time span shorter than for males. Therefore, our data were insufficient to reject Ashkenazie \& Safriel's (1979) hypothesis.

One pair was faithful both to partner and site, breeding close to the previous year's nest site (Table 3). They arrived separately with the male arriving first. At the time of their arrival, there can be 95\% snow cover, so food could be in short supply and nest sites limited. We suggest that pairs return to an area they know to be suitable for nesting and 
rearing young, via experience, and then wait for suitable nest sites to become available when the snow melts. Such a strategy would allow an immediate start to breeding once the thaw begins and increase their likelihood of rearing young by laying early (Perrins 1970). In a year of late thaw, birds were seen scraping through thin snow into the heath. Several nest scrapes can be made although only one is lined and laid in.

The female of this pair (Table 3) was found outside the breeding season on the Scottish east coast (Isle of May, Fife) in August, September and November 1982. The female continued to return to the Isle of May, being recaptured on the island in August 1983 and seen in April and August 1984 (Rae et al. 1986). The male was not seen. Therefore, this pair wintered apart and re-united on the breeding territory.

Overall, the Purple Sandpipers that nest on the Hardangervidda fit the pattern of conservative monogamous sandpipers. Their fidelity to site and mate optimises their chances of breeding success because they can nest earlier by omitting time spent searching for either afresh each year.

\section{Acknowledgements}

This study involved a large number of people and we acknowledge the help in the field by Graham Boag, Ingvar Byrkjedal, Steve Cooper, Brian Cresswell, Brian Cosnette, Keith Duncan, Geoff Flogdell, Clive McKay, Kenny McKinnon, Mick Marquiss, Graham Rebecca, Mike Reid, Innes Sim, Rik Smith, Ian Walker and Graham Wren. K. Brockie was a member of the Cambridge Norwegian University Expedition and acknowledges the help of Chris Cane during field work. The trips were largely self-financed, though we were grateful for additional support from Sir Herbert Bonar, British Petroleum and Development (Aberdeen and Norway), British Trust for Ornithology, the Game Fair and the Scottish Ornithologists' Club. Stein Brykjeland, Hans Schekkerman and Rob van Bemmelen kindly commented on the draft.

\section{References}

Anderson, A. 1975. A method of sexing Moorhens. Wildfowl 26: 77-82.

Ashkenazie, S. \& Safriel, U.N. 1979. Time-energy budget of the Semipalmated Sandpiper Caldris pusilla at Barrow, Alaska. Ecology 60: 783-799.

Bengtson, S.-A. 1975. Observasjoner av hekkebiologien hos fjæreplytt, Calidris maritima, på Svalbard. Fauna 28: 81-86.
Byrkjedal, I. 1989. Habitat use and resource overlap by breeding Golden Plovers and Dotterels (Pluvialis apricaria, Charadrius morinellus). J. Orn. 130: 197-206.

Cane, C. 1979. Observations on the behaviour of the Purple Sandpiper Calidris maritima during incubation and hatching. In Cambridge Norwegian Expedition 1978 Report (ed J.L. Innes). pp 59-66. Cambridge Norwegian Expedition, Cambridge.

Cramp, S. \& Simmons, K.E.L. (eds). 1983. The Birds of the Western Palearctic, Vol. 3. Oxford University Press, Oxford.

Cresswell, B.H. \& Summers, R.W. 1988. A study of breeding Purple Sandpipers Calidris maritima on the Hardangervidda using radio-telemetry. Fauna norv. Ser. C., Cinclus 11: 1-6.

Hallgrimsson, G.T., Palsson, S. \& Summers, R.W. 2008. Bill length: a reliable method for sexing Purple Sandpipers. $J$. Field Ornithol. 79: 87-92.

Innes, J.L. 1979. Wader eggs, and growth rates of wader chicks. In Cambridge Norwegian Expedition 1978 Report (ed J.L. Innes). pp 80-95. Cambridge Norwegian Expedition, Cambridge.

Johnson, D.H. 1979. Estimating nest success: the Mayfield method and alternative. Auk 96: 651-661.

Korte, J. de. 1972. Birds, observed and collected by "De Nederlandse Spitsbergen Expeditie" in West and East Spitsbergen, 1967 and 1968-'69; first part. Beaufortia 19: 113-150.

Lien, L., Østbye, E., Hogstad, O., Haande, K.M., Haande, P.S., Hagen, A., Skar, H.-J., Skartveit, A. \& Svalastog, D. 1974. Bird surveys in the high mountain habitats of Finse and Stigstuv, Hardangervidda, south Norway, 1967-72. Norw. J. Zool. 22: 1-14.

Løvenskiold, H.L. 1964. Avifauna Svalbardensis. Norsk Polarinstitutt, Oslo.

Mayfield, H. 1975. Suggestions for calculating nest success. Wilson Bull. 87: 456-466.

Moksnes, A. 1973. Quantitative surveys of the breeding bird populations in some subalpine and alpine habitats in the Nedal area in central Norway (1967-71). Norw. J. Zool. 21: 113-138.

Nicoll, M., Rae, R., Summers, R.W., Strann, K.-B. \& Brockie, K. 1991. The biometrics of Norwegian and Svalbard Purple Sandpipers Calidris martima. Ring. \& Migr. 12: 67-71.

Norton, D.W. 1972. Incubation schedules of four species of calidridine sandpipers at Barrow, Alaska. Condor 74: 164-176.

Østbye, E., Hogstad, O., Østbye, K., Lien, L. \& Framstad, E. 2002. Structure and dynamics of some high mountain bird communities of South Norway: a 19-year study of passerines. Ornis Norvegica 25: 19-48.

Perrins, C. M. 1970. The timing of birds' breeding seasons. Ibis 112: 242-255.

Pierce, E.P. 1997. Sex roles in the monogamous Purple Sandpiper Calidris martima in Svalbard. Ibis 139: 159-169.

Rae, R., Nicoll, M. \& Summers, R.W. 1986. The distribution of Hardangervidda Purple Sandpipers outwith the breeding season. Scott. Birds 14: 68-73.

Smith, R.D. \& Summers, R.W. 2005. Population size, breeding biology and origins of Scottish Purple Sandpipers. Brit. Birds 98: 579-588.

Summers, R.W. \& Nicoll, M. 2004. Geographical variation 
in the breeding biology of the Purple Sandpiper Calidris maritima. Ibis 146: 303-313.

Swanberg, P.O. 1945. Om skärsnäppan, Calidris m. maritima (BRÜNNICH), i de svenska fjällen och dess häckningsbiologi. Fauna och Flora 40: 108-133, 154-169.

Tomkovich, P.S. 1985. Sketch of the Purple Sandpiper (Calidris martima) biology on Franz Josef Land. Ornithologiya 20: 3-17.

\section{Sammanfattning}

Skärsnäppan studerades åren 1978-1986 inom ett 32 kvadratkilometer stort område på Hardangerviddas fjällhed i södra Norge (Figur 1, Tabell 1). Denna sydliga population är mindre välstuderad än andra, särskilt i jämförelse med den på Spetsbergen. I tre tidigare analyser av materialet från Hardangervidda har de adulta fåglarnas biometri (Nicoll m.fl. 1991), deras ruvningsschema (Cresswell \& Summers 1988) och återfynden av märkta fåglar (Rae m.fl. 1986) redovisats. I denna uppsats kompletterar vi med ytterligare uppgifter om häckningsbiologin.

Totalt påträffades 38 bon och kullar, varav 23 bon. Ett år, 1984, var inventeringen tillräckligt noggrann för att beståndstätheten skulle kunna beräknas. Baserat på funna bon och kullar var tätheten 0,8 par per kvadratkilometer men efter kompensation för boförluster och några missade par bedömdes tätheten ha varit 1 par per kvadratkilometer.

Medelkullstorleken var 3,74 ägg. Äggen var i medeltal $36,2 \mathrm{~mm}$ långa och $25,8 \mathrm{~mm}$ breda ( 8 kullar). Färskvikten låg på 11,9 g i tre kullar. En normalkull om fyra ägg skulle således väga 47,6 $\mathrm{g}$ vilket är 74\% av honans vikt på 64,2 g (Tabell 2). Äggen förlorade i vikt under ruvningen; i ett bo som studerades från 11,7 g till 10,5 g (Figur 3).

Kläckningsdatum (observerat eller beräknat) låg olika år i medeltal mellan 23 juni och 5 juli (Tabell 1). Tolv kullar bevakades under sammanlagt 89 dygn och med hjälp av Mayfields metod kunde häckningsframgången beräknas till 75\% av kullar- na. Ungarnas tillväxt studerades i sju kullar. Medelvikten vid kläckningen var 8,2 g och ökade sedan enligt diagrammen i Figur 2.

Näbben mättes hos sextiosju adulta fåglar (Figur 4). De två topparna vid 25 och $30 \mathrm{~mm}$ motsvarar hanar respektive honor. Bara två fåglar låg $\mathrm{i}$ den tveksamma zonen $27 \mathrm{~mm}$. Den ena hade en tyngre och den andra en lättare partner och var därför sannolikt av olika kön. Med 27,5 mm näbblängd som gräns torde de flesta skärsnäppor i södra Norge kunna könsbestämmas. Fåglarna vägdes också (Figur 5) vilket visade att vikten minskade under säsongens lopp. Separat analys visade dock att det bara var hanarnas viktminskning som var signifikant.

Hemorts- och partroheten kunde inte bestämmas kvantitativt, men en del fåglar kunde konstateras återvända och bilda par med varandra igen. Ett exempel ges i Tabell 3. Hanen återvände fem år och honan tre år och de häckade tillsammans inom 100 meter från boplatsen de hade det första året, och två häckningar låg bara 20 meter från året före. Genom observationer kunde man konstatera att fåglarna $\mathrm{i}$ detta par tillbringade vintern på olika ställen. Hanen återvände före honan till reviret, men båda så tidigt att $95 \%$ av reviret var snötäckt.

Hardangerviddas skärsnäppor var mindre i storlek än i nordligare populationer och hade därför också mindre ägg. Häckningsframgången var god, vilket kan bero på att fåglarna ruvade hårt och var svåra att upptäcka för predatorer. De ruvade över $97 \%$ av tiden, vilket är typiskt för mongama och klart mer än för polygama Calidris-vadare som ruvar bara $80-85 \%$ av tiden. Häckningsbiologin för skärsnäpporna på Hardangervidda skiljde sig inte från vad man funnit i andra studier. Skärsnäpporna på Hardangervidda får betraktas som typiska representanter för de monogama vadarnas strategi att återvända tidigt till kända revir som de av tidigare erfarenhet vet kommer att hålla den kvalitet som behövs för framgångsrik häckning. 